\title{
THE EU'S POLICY IN THE SOUTH CAUCASUS
}

Laure Delcour et Katharina Hoffmann

Centre international de formation européenne | «L'Europe en Formation »

$2018 / 1 n^{\circ} 385 \mid$ pages 7 à 25

ISSN 0014-2808

ISBN 9782855052069

Article disponible en ligne à l'adresse :

https://www.cairn.info/revue-l-europe-en-formation-2018-1-page-7.htm

Distribution électronique Cairn.info pour Centre international de formation européenne.

(C) Centre international de formation européenne. Tous droits réservés pour tous pays.

La reproduction ou représentation de cet article, notamment par photocopie, n'est autorisée que dans les limites des conditions générales d'utilisation du site ou, le cas échéant, des conditions générales de la licence souscrite par votre établissement. Toute autre reproduction ou représentation, en tout ou partie, sous quelque forme et de quelque manière que ce soit, est interdite sauf accord préalable et écrit de l'éditeur, en dehors des cas prévus par la législation en vigueur en France. Il est précisé que son stockage dans une base de données est également interdit. 


\section{The EU and the South Caucasus}




\title{
The EU's Policy in the South Caucasus
}

\author{
Laure Delcour \& Katharina Hoffmann
}

L. Delcour is a researcher in the H2020 project EU-STRAT and a visiting professor at the College of Europe. Previously, she worked as a scientific coordinator of the EU-FP7 project "Exploring the Security-Democracy Nexus in the Caucasus" (CASCADE, Fondation Maison des Sciences de l'Homme). She recently published on the EU and Russia and their "Contested Neighbourhood: Multiple External Influences, Policy Transfer and Domestic Change," London: Routledge, 2017.

$K$. Hoffmann is a post-doctoral researcher under the H2020 project EU-STRAT based at the Centre for Governance and Culture in Europe of the University of St. Gallen where she previously co-coordinated the EU-FP7 project "Intra- and Inter-Societal Sources of Instability and EU Opportunities to Respond." Her recent publications include "Local Government Reforms in Georgia and their Impact on State-Society Relations" in Eurasia Geography and Economics.

\section{Introduction ${ }^{1}$}

This article analyses the European Union (EU)'s policy vis-à-vis Armenia, Azerbaijan and Georgia and the responses of South Caucasus' elites and societies to the EU's offer. The article starts with an overview of the EU's involvement in the region since the collapse of the Soviet Union. It then delves into how EU policies resonate with domestic elites and societies in each country.

The article argues that EU policies in the South Caucasus are fraught with tensions deriving from a mismatch between EU toolbox and local expectations. The growing involvement of the EU in the region is accompanied by an increasing differentiation of EU policies towards the South Caucasus countries in response to their heterogeneous expectations. However, the EU's toolbox-inspired by the EU's own experience-is not well attuned to local priorities.

The article highlights three flaws in EU policies. First, the EU has failed to significantly increase engagement in conflict resolution in the South Caucasus. Second, it has refrained from using political conditionality despite breaches of the rule of law and democratisation setbacks in the region. Third, it has focused on

1. Research for this paper has been supported by the Horizon 2020 research and innovation programme of the EU (project "The European Union and Eastern Partnership Countries-An Inside-Out Analysis and Strategic Assessment” [EU-STRAT]) under grant agreement number 693382 (www.eu-strat.eu). 
wide-scale export of EU standards, which raises questions concerning the EU's acquis capacity to serve as a blueprint for development in these post-Soviet countries. As a result of the above-mentioned shortcomings, the EU's overall influence is limited in a region where other external actors, namely Russia and Turkey, are enjoying long-standing and multifaceted leverages.

\section{The EU and the South Caucasus}

Until the early 2000s, the South Caucasus was not a priority for the EU. After the collapse of the Soviet Union, both the European Commission (EC) and the EU's member states kept a low profile in the region, with only a handful of member states opening embassies in all three countries and an EC delegation in Georgia covering the whole region. Like other post-Soviet countries, Armenia, Azerbaijan and Georgia signed partnership and cooperation agreements (PCAs) with the EU, thereby paving the way for a political dialogue and enhanced economic cooperation with the Union. However, both the belated entry into force of these agreements (1999) and their limited scope as compared to those signed with Russia, Ukraine and Moldova reflect the EU's limited commitment to what was then regarded as a remote region. Importantly, unlike the agreements signed with Russia, Ukraine and Moldova, those signed with South Caucasus countries did not include the objective of setting-up a free-trade area with the EU and, thus, were significantly more limited in scope. Moreover, the EU did not become involved in the mechanisms designed to settle the conflicts that erupted in Georgia with the secessionism of Abkhazia and South Ossetia and those between Armenia and Azerbaijan over Nagorno-Karabakh in the late 1980s-early 1990s. ${ }^{2}$

The EU's growing engagement in the South Caucasus starting in the early 2000s was not the outcome of straightforward and linear dynamics, but was rather a result of a disjointed and chaotic process. While political developments in the region-more specifically the Rose Revolution in Georgia at the end of 2003 - contributed to shifting the EU's attention to the South Caucasus, Armenia, Azerbaijan and Georgia were initially excluded from the European Neighbourhood Policy (ENP) as they were not immediate neighbours of the EU. ${ }^{3}$

\footnotetext{
2. France co-chairs (with the US and Russia) the Minsk Group created by the OSCE to negotiate a peaceful resolution to the Nagorno-Karabakh conflict; the Group also includes other EU member states, i.e. Italy, Germany, the Netherlands, Portugal, Sweden and Finland. Germany, France and the UK (together with Russia and the US) participate in the UN Group of Friends of the Secretary General for Abkhazia.

3. "Given their location, the Southern Caucasus therefore also falls outside the geographical scope of this initiative for the time being." European Commission, Wider Europe-Neighbourhood. A New Framework for Relations with our Eastern and Southern Neighbours, COM (2003) 104 final, Brussels, 2003:4.
} 
Security issues were decisive in raising the EU's awareness of the region's strategic importance, thereby leading to a more active EU role:

"The integration of acceding states increases [the EU's] security but also brings the EU
closer to troubled areas... Even in an era of globalisation, geography is still important.
It is in the European interest that countries on our borders are well-governed... We
should now take a stronger and more active interest in the problems of the Southern
Caucasus, which will in due course also be a neighbouring region." 4

With the appointment of a Special Representative for the South Caucasus in summer 2003 and the integration of Armenia, Azerbaijan and Georgia in the ENP in 2004, the EU gained an enhanced political profile in the region. However, the ENP offered only fuzzy incentives combined with vague conditionality 5 and required unclear commitments from the partner countries. Crucially, the security rationale underlying the ENP did not translate into an increased EU role in conflict resolution in the South Caucasus. ${ }^{6}$ In fact, the EU designed the ENP as "a means of addressing these issues [conflict resolution] indirectly by tackling underlying issues of governance, lack of economic development, insecurity and stability." With the ENP, the EU chose to focus on the partner countries' reform processes as a first step to conflict resolution. It emphasised the role of good governance and rule of law as key drivers of security and stability, even if in the long-term. Both the EU's assistance and conditionality were supposed to drive reforms in key sectors (e.g. justice, security sector reform) with the aim of strengthening democratic institutions and ultimately "contributing to a more positive climate for conflict settlement." ${ }^{8}$ However, this long-term approach premised on the EU's own experience stumbled against regional realities. For instance, the EU's emphasis on the rule of law as a preliminary condition for stability was at odds with Georgia's prioritisation of territorial integrity and reintegration of the breakaway regions. ${ }^{9}$ In addition, the EU's weak involvement in conflict resolution limited its leverage

4. Council of the EU, A Secure Europe in a Better World. European Security Strategy. Brussels, 2003.

5. Gwendolyn Sasse, “The European Neighbourhood Policy: Conditionality Revisited for the EU's Eastern Neighbours," Europe-Asia Studies 60, no. 2, 2008: 295-316.

6. The EU Special Representative to, since 2008, the South Caucasus and the crisis in Georgia, has only in 2006 been given the mandate to contribute to the settlement of conflicts in Georgia and of Nagorno-Karabakh. He also represents the EU in the Geneva International Discussions. This format, established in 2008 is co-chaired by the EU, the OSCE and the UN and address the consequences of the 2008 war between Russia and Georgia for the conflicts with Abkhazia and South Ossetia.

7. European Commission, The European Neighbourhood Policy, quoted in Laure Delcour, "The European Union, a security provider in the eastern neighbourhood?," European Security 19, no. 4, 2010:535-549.

8. EU Commissioner Ferrero-Waldner, Political reform and sustainable reform in the South Caucasus: the EU's approach, Caspian Outlook 2008, Bled Strategic Forum, Slovenia, 2006 http://eu-un.europa.eu/speech-by-eucommissioner-ferrero-waldner-political-reform-and-sustainable-development-in-the-south-caucasus/ (accessed 3 May 2018).

9. Lili di Puppo, "The Externalisation of JHA Policies in Georgia: Partner or Hotbed of Threats?," European Integration 31, no.1, 2009: 103-118. 
over South Caucasus countries and resulted in the EU's promoting conflicting principles in the different countries. For instance, the ENP Action Plan negotiated with Armenia mentioned the right to self-determination whereas the EUAzerbaijan Action Plan referred to territorial integrity.

With the Eastern Partnership launched in 2009, the EU offered to South Caucasus countries a strengthened contractual framework through Association Agreements (AAs) and Deep and Comprehensive Free-Trade Areas (DCFTAs), as well as the gradual liberalisation of the visa regime and increased sectoral cooperation. This enhanced offer was premised upon partner countries' convergence with EU rules and standards. In the absence of a membership perspective, legal approximation with the EU's corpus of rules (the acquis communautaire) was intended to act as a driver of modernisation in the EU's eastern neighbourhood. This focus on legal approximation with EU acquis has three serious flaws. First, the Eastern Partnership's technical offer failed to strengthen the EU's toolbox (and therefore the EU's influence) in terms of conflict resolution. Second, while shifting toward extensive sector-specific and trade-related conditionality, ${ }^{10}$ the EU did not make political changes a precondition for closer ties with the South Caucasus countries, even though there were considerable concerns over the rule of law in some of the countries within the region. ${ }^{11}$ Third, the wide-scale export of EU standards and rules raises key questions in terms of the EU acquis' capacity to serve as a blueprint for development in post-Soviet countries. The discrepancy between the acquis and the partner countries' socio-economic context may actually hinder the adoption and application of EU templates, and therefore hamper the EU's transformative power in the region.

This calls for an in-depth analysis of South Caucasus countries' responses to the EU's offer of integration. The following three sections will highlight key dynamics triggered by the above described flaws in the EU's policies to inspire the discussion about alternative tools to better serve the EU's aim, namely to increase its visibility and leverage as a player in its eastern neighbourhood.

\section{Armenia's Response to the EU}

Armenia's response to the EU's offer as part of the ENP/Eastern Partnership mirrors a strong degree of continuity in a fast-changing regional context. It is premised upon both a high receptivity to the EU's model and a lingering sense of disillusionment with the EU's security capacity. To some extent, these perceptions have been shared by the country's elites and the general public, not least because

10. Nariné Ghazaryan, The European Neighbourhood Policy and the democratic values of the EU. Oxford and Portland: Hart Publishing, 2014.

11. Laure Delcour, Kataryna Wolczuk, "Spoiler or facilitator of democratization?: Russia’s role in Georgia and Ukraine," Democratization 22, no. 3, 2009: 462. 
of the latter's limited awareness of EU policies. However, attitudes towards the EU also highlight a persisting mismatch between the elites under the presidency of Serzh Sargsyan and civil society organisations pushing for deep reforms in the country. Such a discrepancy may become critical in light of the recent political upheavals in Armenia.

Despite the lack of aspirations to join the EU, Armenia welcomed the EU's offer under the Eastern Partnership. This is because it coincided with the emerging modernisation agenda of the Armenian authorities.

While Armenia had introduced structural reforms after the collapse of the Soviet Union, the transformation process was largely affected by the conflict with Azerbaijan. The latter thwarted further attempts to carry out reforms and led to the emergence of powerful commodity-based cartels tightly connected to the political elite. The country's attitude toward reform and response to the EU's offer drastically changed at the end of the 2000 s as a result of both geopolitical and domestic factors. The 2008-2009 economic crisis hit the country severely and exposed its structural weaknesses, including an overreliance on remittances. In the wake of the crisis, Armenia suffered from a rise of poverty and widening socioeconomic disparities. Modernisation also emerged as an imperative for Armenian authorities' survival in the wake of the 2008 presidential elections that were marred by post-electoral violence and resulted in sharp political polarisation. ${ }^{12}$

In this context, the Eastern Partnership entailed significant promise as it offered a template for modernisation. In a highly polarised political climate after the 2008 post-electoral violence, an overarching consensus thus emerged amongst domestic political actors on the benefits of closer relations with the EU, at a time when the Union extended tangible incentives to South Caucasus countries (e.g. the prospect of association agreements and DCFTAs) that had thus far been on the table with Ukraine only. For the incumbent elites, this was seen as a means to defuse tensions with the political opposition while also offering the promise of tangible results in terms of modernisation. In addition, the EU's offer under the Eastern Partnership minimised the political costs which would have to be incurred by a ruling elite that was closely connected to commodity-based cartels and unwilling to engage in deep and comprehensive democratisation. ${ }^{13}$

Therefore, between 2010 and 2013 Armenia embarked on substantial traderelated reforms in line with EU demands. The country quickly completed negotiations for a DCFTA and was expected to initial an association agreement at the Eastern Partnership summit in Vilnius in November 2013. Crucially, in

12. Laure Delcour and Kataryna Wolczuk, “The EU's Unexpected 'Ideal Neighbour'? The Perplexing Case of Armenia’s Europeanisation,” Journal of European Integration 37, no. 4 (2015): 491-507.

13. Laure Delcour, The EU and Russia in their "Contested Neighbourhood". Multiple External Influence, Policy Transfer and Domestic Change. London: Routledge, 2017. 
the eyes of Armenian elites, closer integration with the EU did not run counter the country's strategic alliance with Russia. In fact, Armenia never gave an equal weight (even if only in its foreign policy strategy) to Russia and the West. Rather, it strove to develop new partnerships with NATO, the EU and Western countries with the view to opening up new opportunities and complementing its alliance with Russia. The latter remained pivotal for the country's security, yet (in sharp contrast to the EU) was never regarded as a legitimate model for Armenia's modernisation. In essence, the Armenian authorities regarded economic reforms in line with EU templates as compatible with the country's security alliance with Russia. ${ }^{14}$ However, Russia perceived the Eastern Partnership as an attempt to organise a regional group in its own backyard without its participation, thereby contradicting its interests in the region. ${ }^{15}$ Therefore, in 2013 Russia increased its pressure to lure Armenia in its own regional integration project, the Eurasian Customs Union that was upgraded to the Eurasian Economic Union (EAEU) in 2015. Russia's pressure ${ }^{16}$ was instrumental in the Armenian president's decision to join the EAEU, therefore renouncing to initial the AA and DCFTA with the EU. ${ }^{17}$ This backtracking has to do with the fact that Armenia's policy is filtered through the Nagorno-Karabakh conflict, in which Russia's security alliance is vital for Yerevan. By targeting Armenia's overarching priority, Russia was able to overturn the country's plans for a framework of economic integration.

While President Sargsyan's decision to join the EAEU came as a surprise to many in Armenia, it did not raise substantial criticism in the society. This is because of three factors. First, negotiations for an AA/DCFTA were conducted by small groups of experts, with limited awareness of the agreements and their implications among the general public. Second, Russia is strongly perceived as the country's security guarantee, while the EU is regarded as a weak security player. With the Safarov case in 2012, ${ }^{18}$ many in Armenia realised that decisions by some EU Member States could-even though unintendedly-bring additional

14. L. Delcour, K. Wolczuk, “The EU's Unexpected 'Ideal Neighbour??, 492.

15. Andrey Zagorski, "Eastern Partnership from the Russian perspective," Internationale Politik und Gesellschaft, no. 3, (2011): 47.

16. E.g. threats of a $70 \%$ surge in energy prices and, especially, the conclusion of a deal with Azerbaijan envisaging the sale of weapons for the sum of approximately $€ 4$ billion. Eastern Partnership Civil Society Forum, Open Society European Policy Institute, International Renaissance Foundation, PASOS, 2015: 51.

17. Membership in the EAEU entails a delegation of sovereignty in trade-related issues (especially tariffs) which excludes the signature of a DCFTA by the member states.

18. An Azerbaijani officer, Ramil Safarov, brutally murdered an Armenian lieutenant with an axe in Hungary in 2004 and was imprisoned there until 2012, when Hungary decided to extradite him to Azerbaijan. Safarov received a hero's welcome upon returning to Azerbaijan. He was pardoned by Azerbaijani President Aliyev despite contrary assurances made to Hungary, promoted to the rank of major and given an apartment and over eight years of back pay. Armenia reacted by suspending ties with Hungary. 
insecurity without triggering any condemnation by the bloc. ${ }^{19}$ The EU's role in the conflict in Ukraine was interpreted as a confirmation of its intrinsic weakness and helplessness vis-à-vis Russia's blunt behaviour. It only reinforced the belief shared by many in Yerevan that Armenia did not have much of a choice in terms of deep economic integration. Third, while the EU is broadly regarded as a beacon of democracy and prosperity, it has growingly been associated (among others in the media) with other values that carry a negative connotation in Armenia, namely the defence of LBGT rights.

However, the EU's influence in Armenia did not stop with the country's backtracking from the Association Agreement/DCFTA. Despite the country's accession to the EAEU in 2015, the Armenian authorities have attempted to maintain (and even to expand) the links with the EU. This is primarily because the reasons that prompted Armenia to embrace EU templates under the Eastern Partnership have not vanished. As emphasised by President Sargsyan during the Vilnius EaP Summit in 2014, the EU is still regarded as a model for Armenia's modernisation:

"Building and strengthening Armenian nationhood upon a European model has been a conscious choice of ours, and that process is hence irreversible. Our major objective is to form such mechanisms with the EU that, on the one hand, would reflect the deep nature of our social, political and economic relationship, and on the other-would be compatible with other formats of co-operation." 20

In line with this narrative, the Armenian government intends to "act as a bridge" between the EU and the EAEU, ${ }^{21}$ by encouraging the diffusion of EU standards (whenever possible) within the Eurasian Union. ${ }^{22}$ While this role of a bridge-builder is unlikely to materialise in the near future due to the weak prospects of a dialogue between the EU and the EAEU, Armenia has negotiated and signed a new agreement with the EU that takes into account its obligations as an EAEU member. In spite of obvious limitations in trade-related and (to a lesser extent) foreign policy issues, the Comprehensive Enhanced Partnership Agreement (CEPA) paves the way for a wide-ranging cooperation between Armenia and the EU.

The way in which EU-Armenia relations will develop crucially hinge on a combination of domestic and regional factors. The massive demonstrations in

19. The EU expressed its concern, but did not condemn either Hungary's decision or Aliyev's move. See statement by the spokespersons of EU High Representative Catherine Ashton and Commissioner Štefan Füle on the release of Ramil Safarov, 3 September 2012, http://www.europarl.europa.eu/meetdocs/2009_2014/documents/ dsca/dv/dsca_20121025_18/dsca_20121025_18en.pdf (accessed 3 May 2018).

20. Statement by Serzh Sargsyan, President of the Republic of Armenia at the Third Eastern Partnership Summit, Vilnius, 29 November 2013, <http://www.president.am/en/statements-and-messages/item/2013/11/29/ President-Serzh-Sargsyan-at-the-third-Eastern-Partnership-summit-speech/> (accessed 22 June 2016).

21. Author's interview, Ministry of Foreign Affairs, Yerevan, March 2015.

22. Author's interview, Ministry of Economy, Yerevan, March 2015. 
April 2018 that led to the resignation of the newly appointed prime minister (and former president) Serzh Sargsyan highlight a strong demand for effective reforms and democratisation in the Armenian society. In recent years, Armenian NGOs have voiced criticisms vis-à-vis the EU for not fostering accountability of Armenian politicians and refraining from the use of political conditionality. The new authorities have seemingly placed the fight against corruption at the forefront of their reform efforts, which may in fact bring the country closer to EU values and templates. However, they have also made it clear that relations with the EU will not take precedence over the strategic partnership with Russia. Despite the change of power, Moscow remains Armenia's security guarantee-a role that the EU is not able to play in the eyes of many in Armenia. The strengthening of EU-Armenia cooperation seems to be endorsed officially by Russia as long as it does not contradict Armenia's EAEU commitments. However, Armenia's autonomy is precarious given the country's multifaceted dependence on Russia.

\section{Azerbaijan's Response to EU's Policy}

The three flaws - the EU's low profile in conflict resolution, the lack of political conditionality and the concentration on the EU acquis export-prominently feature in the mostly critical assessment of Azerbaijan's relations with the EU by government officials, analysts and civil society activists in Azerbaijan. While both the ruling elite and civil society jointly criticise the EU's failure to address Azerbaijan's immediate security needs, the two groups try to push the EU into different directions with regard to political conditionality and sector reform demands. The key issue of contestation is value-free versus value-driven EU foreign policy. Having incomparably more leverage, the incumbent elite has since 2013 increasingly managed to sideline the EU's normative agenda, while the room for civil society actors to demand support for domestic political and economic reforms is shrinking.

In 2010, Azerbaijan has initially agreed to the offer to negotiate an AA with the EU. However, three years later, shortly before the biennial Eastern Partnership summit, Azerbaijan has declared not to proceed with the negotiations but to aim at an alternative framework for its relations with the EU.

Azerbaijani government officials have invoked a variety of reasons for this decision. In rather formal terms, they framed the AA as a tool serving ultimately EU membership ambitions which Azerbaijan never had. More outspokenly, other statements see the AA as a "unilateral instruction list" and stress that Azerbaijan does not want to obey by the EU's normative agenda. Crucially, by blaming the EU for applying double standards, government officials have discredited the im- 
age of the EU as a normative agent. ${ }^{23}$ Two issues raise contention. The first is the EU's emphasis of the right to self-determination vis-à-vis Armenia, which is perceived as strengthening Armenia's support of Nagorno-Karabakh's secessionism, and simultaneous statements of support for Azerbaijan's territorial integrity. Moreover, Azerbaijan blames the EU to deny Azerbaijan the degree of support for territorial integrity it provides to Georgia and Ukraine. The fact that the Joint Declaration of the Eastern Partnership Summit in 2015 refers to Georgia's and Ukraine's but not Azerbaijan's territorial integrity ${ }^{24}$ was taken as an offence. The Joint Declaration of the following Summit in 2017, however, was treated as a foreign policy success in Azerbaijan since it mentions support for the territorial integrity of all Eastern Partnership countries.

Secondly, in the eyes of the ruling elite, any criticism on the current political regime, in particular the treatment of civil society activists, is also an incident of double standards. The argument is that the EU is biased when politicising court decisions or looks into the domestic situation of Azerbaijan without scrutinising undemocratic developments in other Eastern Partnership member states. ${ }^{25}$ The peak was reached in 2015, when the European Parliament responded to the growing number of detained human rights activists, journalists and NGO leaders in a resolution demanding to halt negotiations on a cooperation framework with Azerbaijan until respect for human rights in Azerbaijan improved. Upon this resolution Azerbaijan disrupted several ways of communication with the EU for several months, including participation in the parliamentary assembly EURONEST and meetings with the EEAS.

The rationales behind the outlined rhetoric and action root in both domestic and international dynamics. In the light of Azerbaijan's official criticism on the EU's response to Azerbaijan's security needs, one should not overlook that the economic and political transformative agenda of the AA had little chance to attract compliance of the incumbent elite. The current regime builds on neopatrimonial patterns that, in oversimplified terms, rely on compromised rule of law, elite control over access to resources and limited societal participation in economic and political endeavours. ${ }^{26}$ The AA, however, pursues bilateral relations conditioned on impartial application of law, broad economic participation by avoiding monopolies and call for wide societal participation. This diametrically opposed agenda has always made the AA unattractive for Azerbaijan's ruling

23. Rahim Rahimov, "Armenia and Azerbaijan: What Do They Seek From the EU?," Eurasian Daily Monitor 14, no. 40, 24 March 2017. https://jamestown.org/program/armenia-azerbaijan-seek-eu/ (accessed 25 April 2018).

24. Council of the European Union, Joint Declaration of the Eastern Partnership Summit, 22 May 2015. https://www.consilium.europa.eu/media/21526/riga-declaration-220515-final.pdf (accessed 20 February 2018).

25. AZERTAC, “Azerbaijan's parliament slams European Parliament for 'biased' anti-Azerbaijani resolution”, September 16, 2015. https://azertag.az/en/xeber/885307 (accessed 03 April 2018).

26. Farid Guliyev, "Oil and Regime Stability in Azerbaijan”, Demokratizatsiya 21, no.1(2013):122. 
elite. ${ }^{27}$ Similar reasons constrain the ruling elite's interest in the WTO membership so that Azerbaijan has for years been in the process of membership negotiations. However, unless Azerbaijan gains WTO membership, a DCFTA is no option for Azerbaijan and trade needs to be negotiated in another framework. What decreases incentives of the AA further is that, as Leila Alieva argues, Azerbaijan's government and business elite "is already 'integrated' into the EU with its assets, business and property." 28

Moreover, Azerbaijan's economic performance has since 2013 been negatively affected by the declining oil price. Between 2013 and 2016 Azerbaijan's GDP dropped by almost $50 \%$, which raised the potential for societal tensions with an anti-government tune as indeed occurred in January 2015. This created incentives for the ruling elite to minimise the legitimacy of external criticism on the state of democracy in the country. First steps in this direction were to restrain from formally committing to political values and EU-shaped economic reforms by withdrawing from the AA and to publicly discredit the EU's normative agenda. Thus, unlike in Armenia, the recent economic crisis did not increase the AA's attractiveness. It rather induced government authorities to take a more distanced stance.

Putting the AA on hold also nourished a key pillar of President Ilham Aliyev's public support. For several years, the ruling elite has promoted foreign policy and cultural diplomacy as a stepping-stone for international visibility and ultimately international support of Azerbaijan's territorial integrity and the resolution of the Nagorno-Karabakh conflict. Declining the AA highlighted, in the narrative of the government, once more the willingness and power of the current government to pursue an independent foreign policy vis-à-vis regional powers. Azerbaijan's initiative to draft an alternative framework for the EU resonated particularly strongly with this approach. The initial proposal, a non-binding document on a "Strategic Modernisation Partnership," did not fall on fruitful ground. But in 2016, the EU has accepted to negotiate on a Strategic Partnership Agreement (SPA) proposed by the Azerbaijani government in late 2015. With reference to the European Neighbourhood Policy Revision of 2015, Azerbaijan presented the SPA as opportunity for the EU to commit to a differentiated neighbourhood policy with the partners' strong ownership. So far, it is indeed one of the few

27. Sabina Strimbovschi, "Azerbaijan's Balanced Foreign Policy Trapped in a Volatile Geopolitical Context," Europolity 10, no.1 (2016): 128.

28. ECFR, "Riga Series. View from EAP Countries," (Spring 2015):9. http://www.ecfr.eu/page/-/Riga_Series_ EAP_Countries.pdf (accessed 25 April 2018). 
examples of where a neighbourhood country has leverage to actually significantly alter the EU's policy. ${ }^{29}$

The SPA has been under negotiation since February 2017. Both the EU officials and the Azerbaijani side report progress, but have not yet announced a timeframe for its completion. It will have a political, trade, investment, transport, security and cultural dimension with Azerbaijan's strong emphasis on trade and transport. The EU is Azerbaijan's largest trade partner, accounting for roughly $50 \%$ of its trade turnover. ${ }^{30}$ It is noteworthy that the EU is becoming an increasingly important partner also for Azerbaijan's non-oil exports, which Azerbaijan will have to expand in the near future. Enhanced access to the European market is, therefore, crucial for Azerbaijan. Besides the SPA, a number of agreements and financial instruments structure the relations with the EU. The most central initiative is the Southern Gas Corridor, which is planned to become a central building block for the European energy security. ${ }^{31}$ Azerbaijan emphasises its key role in the project and, thus, the leverage it has on Europe's energy future by taking the lead in key working committees and events. Azerbaijan is financially more potent than in the 1990s. However, for development in its region, the country still draws on technical cooperation provided by the EU. Moreover, Azerbaijan continues to request EU twinning projects for the state administration. Overall, the ruling elite has significant interest in good relations with the EU, but also enough influence for shaping the rules of the game.

To avoid further critical reaction from EU institutions, Azerbaijan balances its stance on the EU's normative agenda by allowing for continued engagement of NGOs in the Eastern Partnership civil society forum. In this frame, the government authorities even welcome NGO activities that raise awareness in Europe for the Nagorno-Karabakh conflict. ${ }^{32}$ At the same time, the government has imposed measures to constrain the domestic outreach of NGO activities. Since 2014, NGOs have been lacking resources for staff and activities due to severe constraints in the acquisition of external funding. Furthermore, detentions and sentences of leading activists have damaged the general reputation of this kind of societal organisation and decreased trust in their activities. Beyond this, NGO representatives report to struggle increasingly to reach out to govern-

29. Elena A. Korosteleva et al, "The political' and the ENP. Rethinking EU relations with the Eastern region," in Theorizing the European Neighbourhood Policy, ed. Sieglinde Gstöhl and Simon Schunz (London: Routledge), 235 .

30. Based on data of The Observatory of Economic Complexity. https://atlas.media.mit.edu/en/visualize/tree_ map/hs92/export/aze/show/all/2015/ (accessed 10 July 2018).

31. The Southern Gas Corridor will provide Europe with gas from Azerbaijan through Georgia, Turkey, Greece and Italy in a pipeline network of 3500 kilometres. First deliveries are planned for 2020.

32. Author's interview with NGO representatives and state officials in Azerbaijan in May 2015. 
ment officials. ${ }^{33}$ Thus, civil society organisations have extremely limited scope for engagement with the ruling elite, but also with the society. Accordingly, it is not surprising that unlike in Ukraine, the government's decision to abandon AA negotiations was made without any visible reaction from the population.

Given these deteriorating conditions for NGOs, civil society actors perceive the EU's decision to prioritise further engagement with Azerbaijan's incumbent elite rather than supporting civil society organisations with democratic normsrelated conditionality as an incident of double standards. The EU, thus, has failed to meet the expectations of Azerbaijan's civil society. ${ }^{34}$

Since negotiations of the SPA with the EU are not yet completed, it is too early to conclude to what extent authorities in Azerbaijan have managed to push aside EU's acquis and the normative agenda. However, the case of Azerbaijan clearly shows the limited attractiveness of the EU's neighbourhood toolbox for the ruling elite. From the perspective of the civil society, it is particularly the readiness of the EU to deviate from the normative fundament which disheartens Azerbaijan's civil society actors. It remains to be seen whether the acknowledgement of the elite interests combined with continuing transfer of norms through technical cooperation will, in the end, strengthen the EU's ambition to be a transformative power or will urge it to drop this ambition.

\section{Georgia's Response to the EU}

With strong societal support, Georgia's governments have been striving for European integration for almost two decades. Indeed, the country's relations with the EU have substantially intensified with the AA and the DCFTA, in force since 2016, and the waiver for visas for short-term stays since 2017. However, the path towards association with the EU was and is marked by disillusion concerning the EU's acknowledgement of and commitment to Georgia's national security priorities. While this disillusion did not alter Georgia's foreign policy agenda, it encouraged the government to compromise for the sake of progress. This, however, comes with the risk of creating shallow reforms and losing people's support.

From the early 1990s onwards, but particularly after the Rose Revolution in 2003, the EU was in the focus of Georgia's security policy. In the light of the secessionist conflicts and Russia's support of the breakaway regions, Georgia's governments continuously viewed close ties with Western actors as a security guarantee. Based on this rationale, Georgia's ruling elite developed membership aspirations-initially for NATO, later for the EU-and demanded the two or-

33. Author's interview with NGO representatives in Azerbaijan in May 2015 and January 2018.

34. Eske van Gils, "Differentiation through bargaining power in EU-Azerbaijan relations: Baku as a tough negotiator," East European Politics 33, no. 3 (2017): 396. 
ganisations to support Georgia's security capacity and to engage in peacemaking. Given this overarching security perspective, it is not surprising that the EU gained centre stage in Georgia's foreign policy after NATO had cooled down Georgia's ambitions by denying a Membership Action Plan in 2008..$^{35}$ For this stronger emphasis on the EU, the government could draw on the population's support since pro-EU voices have always been slightly higher than NATO-membership support.

The post-Rose Revolution government under Saakashvili framed Georgia's commitment to the EU as a necessity for Georgia's freedom, democracy, independence and peace ${ }^{36}$ and entered the period of intensified cooperation with the EU as a demanding neighbour. Like the other South Caucasus countries, Georgia became part of the ENP in 2004, which Saakashvili initially saw as a chance to gain more EU engagement in Georgia's key security challenge, the secessionist conflicts with Abkhazia and South Ossetia. However, as indicated above, the EU was rather reluctant to respond to Georgia's demands in this regard. The EU signalled attention to conflict resolution with the appointment of an EU Special Representative for the South Caucasus in 2003. However, only after the RussianGeorgian five-days war in 2008, the EU got explicitly involved in peace-making and peace-keeping only through the EU Monitoring Mission and through engagement in the security sector reform. ${ }^{37}$ Overall, Saakashvili's initiatives in the first ENP years to shape the agenda of the initial ENP instrument, the Action Plan, did not have the expected results and produced some disenchantment among the ruling elite. ${ }^{38}$

New enthusiasm created the Eastern Partnership, which Georgia's authorities and the general public perceived as the European response to Russia's aggression. Moreover, in the Georgian view, the five-day war also highlighted that the EU had contributed substantially to end Russia's aggression with the ceasefire agreement negotiated by Nicolas Sarkozy, who at that time presided the Council of the EU. This encouraged calls for further EU security engagement. However, there

35. Ketevan Bolkvadze, "Cherry Picking EU Conditionality: Selective Compliance in Georgia’s Hybrid Regime," Europe-Asia Studies 68, no. 3 (May 2016): 432.

36. Licinia Simao, The EU's Neighbourhood Policy towards the South Caucasus, London: Palgrave Macmillan, 2018, 225.

37. Sebastian Mayer, "The EU and NATO in Georgia: complementary and overlapping security strategies in a precarious environment," European Security 26, no. 3 (2017): 444.

38. Kataryna Wolczuk, Laure Delcour, Rilka Dragneva and Klaudijus Maniokas, "The Association Agreements as a Dynamic Framework: Between Modernisation and Integration,” EU-STRAT Working Paper no. 6 (September 2017): 26 . 
is also disillusion about the EU refraining from a strong response to emerging security threats such as Russia's borderisation tactics. ${ }^{39}$

In the field of political and economic cooperation with the EU, resistance to adopt EU regulations and norms initially marked Saakashvili's approach. The Saakashvili administration questioned the relevance of EU norms and their applicability to Georgia. Given that these fields initially had a secondary rank, Georgia's newly ruling elite was not ready to fully comply with the EU demands set out in the ENP Action Plan and-since 2009-with the conditionality related to the AA. Under Saakashvili, Georgia's EU compliance was driven by two interlinked concerns. On the one hand, the ruling elites were eager to maintain the neopatrimonial structures on which their power rested. On the other hand, Saakashvili was committed to rapid reforms with a strong emphasis on deregulation, which contradicted the EU's agenda. In this light, Saakashvili demonstrated an intransigent stance on crucial EU demands such as the competition regulation and food safety regulations. Moreover, in the area of visa liberalisation, which promised to generate public support, Saakashvili pursued the strategy of selective adjustment to EU requirements. This strategy allowed the government to signal progress in convergence with EU norms without compromising their own approach to migration. ${ }^{40}$

Both the AA and the visa-liberalisation negotiations were finalised under the Georgian Dream - Democratic Georgia (GDDG) government, despite the initial fears that the new ruling elites might de-prioritise the EU in Georgia's foreign relations. The GDDG government was instead committed to rapidly finalise negotiations and was ready to adjust Georgia's legislation to EU regulations, demanding less consideration of the domestic conditions in Georgia. This speedy process of reform, however, causes some concerns on the sustainability and actual implementation. ${ }^{41}$ With regard to the AA/DCFTA, one concern is the fact that the agreement is only partially driven by economic rationales. While the DCFTA has a certain economic basis, given that the EU is a key trade partner for Georgia, it does not respect Georgia's economic needs in all regards. Analysts based in Georgia explain this through the political and security priorities that have also driven the negotiation and adoption process. ${ }^{42}$ In case of full implementation,

39. Borderisation denotes the unilateral installation of border markers, fencing and barbed wire along the administrative borderlines between Abkhazia, South Ossetia and the rest of Georgia, which slightly expands the territory of the de facto states and therefore violates the 2008 ceasefire agreement. Cf. https://www.nytimes. com/2016/10/24/world/europe/in-russias-frozen-zone-a-creeping-border-with-georgia.html.

40. Laure Delcour, "Meandering Europeanisation. EU policy instruments and policy convergence in Georgia under the Eastern Partnership," East European Politics 29, no. 3 (2013):353.

41. Esther Ademmer and Laure Delcour, "With a little help from Russia? The European Union and visa liberalization with post-Soviet states," Eurasian Geography and Economics 57, no. 1 (2016):103.

42. Bret Barrowman and George Welton, "What Extent Does Economic Comparative Advantage Constrain Foreign Policy Decision Making in the Caucasus?,” unpublished work (2017). 
the DCFTA is expected to come with a number of negative effects for Georgian businesses. One issue is the new food safety regulations, which are an immense burden for Georgia's large group of small-scale agricultural entrepreneurs since they will not only transform the export, but also the domestic market. In addition, some effects of the AA on the market structure may have negative impact for businesses that are oriented towards Russia. ${ }^{43}$ Thus, the challenges of the AA for the Georgian government are higher than just its formal implementation. In this light, the ruling elite can be expected to purport rather than fully implement the AA.

Georgia has to already put another $\log$ on the fire for the visa liberalisation deal. A year after the visa waiver, European voices demand reaction to the high number of asylum seekers and irregular migrants from Georgia. The GDDG government immediately announced some legal reforms and an information campaign to avoid talk about a suspension of the visa-free regime. A suspension of this for Georgian citizens most tangible EU agreement would tremendously damage the image of the current government both internationally and in the eyes of the general public.

Thus, while the Saakashvili objected adjustment to the EU in order to transform the country according to his own vision, the GDDG government in absence of a comparably strong vision was more inclined to formally accept the EU's transformative agenda. The current government continues to frame the EU integration as a function of Georgia's security policy. In this light, government authorities depict both the visa liberalisation and the AA/DCFTA as a means to raise Georgia's attractiveness for the population living in the de facto states $\mathrm{Ab}$ khazia and South Ossetia. Leading politicians also uphold the vision of deeper $\mathrm{EU}$ integration. Asked at the day when the AA was signed for prospects of EU membership, Prime Minister Garibashvili stated:

"Unofficially we applied for membership today; officially-it depends on progress that we will make, but I can guarantee you that we will do our best to meet all the requirements of the European Union." "44

Georgia's European aspirations receive vibrant support from a well-developed civil society landscape that emerged in the 2000s before and after the rose revolution. It served as a watchdog of the government's commitment to European values and standards already under Saakashvili and continues to do so today. The country's deep involvement in the EU integration processes provides NGOs additional mechanism of leverage vis-à-vis the government such as appealing di- 
rectly to the European Commission with the pledge to more closely monitor certain developments.

Public opinion polls conducted between 2011 and 2017 indicate a strong, but in recent years declining public support for the government's EU policy. While up to $70 \%$ voiced support for EU membership in the phase of the AA/DCFTA negotiations, the number declined after 2013 with an upward trend since 2015. The number of clear-cut EU membership proponents reached only $45 \%$ in 2017 , while $28 \%$ were not in favour of, but also did not actively reject this perspective. Given that large parts of the population are unaware of the key elements of Georgia's EU relations, these figures cannot be interpreted as informed responses to the government's EU policy. It is, however, noteworthy that the figures roughly correlate with more pronounced anti-Western tunes in Georgian media. According to a media monitoring between 2014 and 2016, a growing number of media outlets disseminate predominantly either anti-Russian or anti-liberal values referring to Russia as a single provider of security and discrediting i.a. the EU as contradicting Georgian traditional values. ${ }^{45}$ With the change of government in 2012, factions and societal groupings that oppose the government's EU commitments gained visibility, but are still marginal, bringing together not more than a few hundred people in public gatherings. However, civil society organisations appear to be increasingly alarmed by this phenomenon and urge the government to improve its EU-related public diplomacy through information campaigns.

Overall, Georgia stands out in the South Caucasus as a country in which both government authorities and large parts of the civil society lobby for the country's future in the EU framework. This rationale is, in particular in the view of the ruling elite, motivated by security concerns rather than by support of the EU norms transmitted in the EU's acquis. Integration ambitions shall tie the EU closer to Georgia as a supporter of Georgia's security. In this light, the EU's focus on the export of its legal framework creates incentives for shallow instead of substantial reforms.

\section{Conclusion}

Comparing the dynamics of the EU's policy and Armenia's, Azerbaijan's and Georgia's responses to it highlights an increasing differentiation in the toolbox with which the EU conducts its relations with these countries. Thus, the readiness announced the 2015 ENP review to replace the one-size-fits-all approach with tailor-made, differentiated policies appears to materialise increasingly. While Georgia's relations with the EU build on the AA/DCFTA, the EU offered Armenia a Comprehensive Enhanced Partnership Agreement and agreed to negoti-

45. Girogi Menabde, Eurasian Daily Monitor, 11 May 2007. 
ate a Strategic Partnership Agreement upon Azerbaijan's request. The analysis, however, shows that the differentiation has not necessarily led to the envisioned increasing effectiveness and visibility of the EU in the region so far. The analysis highlights that the current approaches still come with three significant flaws. Firstly, by not substantially upgrading its engagement in conflict resolution, the EU fails to respond to the countries' security needs. The EU does not rise to a key security provider in the region. Secondly, by largely abandoning political conditionality, the EU appears to accept undemocratic developments in the partner countries and loses, in the eyes of civil society organisations, its image as a democracy promoter. This holds particularly true for Azerbaijan. To what degree the $\mathrm{EU}$ is able to promote democracy through further engagement remains to be seen. Finally, the extensive reliance on the export of the EU's acquis often fails to meet the countries' needs as all three cases show. In Azerbaijan, the emphasis on the acquis export produced alienation and led the country to use its leverage in EU energy security matters to apply an alternative approach. Lacking such power, Georgia responded with shallow reforms. In the case of Armenia, the EU's agenda had to be adjusted substantially after Russia's interference in the country's legal adjustment to the EU. In light of these findings, we suggest the following recommendations for EU action:

\section{Recommendations to the EU:}

- To condition closer links with the EU to reach progress in the rule of law, democratisation and good governance and-as recommended by the European Parliament-ensure that political prisoners are freed before the end of negotiations for a new agreement with Azerbaijan;

- To be flexible in the approximation with the acquis (primarily in Georgia); this does not mean accepting a shallow adoption and/or implementation in all areas, but rather prioritising the adoption and implementation of EU acquis in those areas where it will have a clear added value for the country's development;

- To encourage dialogue between governing elites and civil society over the country's EU policy in order to foster the involvement of both;

- To develop, clearly define and communicate possibilities and limits of the EU's engagement in conflict resolution in the South Caucasus in order not to raise wrong expectations.

\section{Recommendations to the South Caucasus governments:}

- To invest more into communicating the EU policy, the advantages and burdens that come with it, to the general public in order to generate and 


\title{
maintain support for the approximation with the EU, even in times when
} the burden of EU demands, e.g. the DCFTA, become tangible;

- To foster cultural and religious dialogue with EU member states to mitigate anxieties of clashing values.

\begin{abstract}
In this paper, we analyse how Armenia, Azerbaijan and Georgia respond to and try to shape the EU's South Caucasus policy. The EU has since the zooos developed differentiated policies for the three countries. We ask to what extent this differentiation supports the EU goals of strengthening impact and visibility in the region. We argue that the EU's policies come with three flaws. First, the EU has failed to significantly increase engagement in conflict resolution in the region. Second, even though there were considerable concerns over the rule of law in some of the South Caucasus countries, the EU has refrained from using political conditionality. Third, the EU has focused on wide-scale export of EU standards, which raises questions concerning the EU's acquis capacity to serve as a blueprint for development in these postSoviet countries.
\end{abstract}

\section{Résumé}

Dans cet article, nous analysons comment l'Arménie, l'Azerbaïdjan et la Géorgie réagissent et essaient de façonner la politique de l'UE dans le Caucase du Sud. L'UE a développé depuis les années 2000 des politiques différenciées pour les trois pays. Nous nous demandons dans quelle mesure cette différenciation appuie les objectifs de l'UE visant à renforcer l'impact et la visibilité dans la région. Nous soutenons que les politiques de l'UE ont trois défauts. Premièrement, I'UE n'a pas réussi à accroître significativement son engagement dans la résolution des conflits dans la région. Deuxièmement, même si l'état de droit suscitait de vives inquiétudes dans certains pays du Caucase du Sud, l'UE s'est abstenue d'utiliser la conditionnalité politique. Troisièmement, I'UE a mis l'accent sur l'exportation à grande échelle des normes de l'UE, ce qui soulève des questions concernant la capacité de l'acquis de l'UE à servir en tant que modèle pour le développement dans ces pays post-soviétiques. 